Review

\title{
Synthetic Strategies for the Fabrication of Cationic Surface-Modified Cellulose Nanocrystals
}

\author{
Rajesh Sunasee ${ }^{1, *}$ and Usha D. Hemraz ${ }^{2}$ \\ 1 Department of Chemistry, State University of New York at Plattsburgh, Plattsburgh, \\ New York, NY 12901, USA \\ 2 National Research Council, 6100 Royalmount Avenue, Montreal, QC H4P 2R2, Canada; \\ usha.hemraz@nrc-cnrc.gc.ca \\ * Correspondence: rajesh.sunasee@plattsburgh.edu; Tel.: +1-518-564-2703
}

Received: 5 February 2018; Accepted: 28 February 2018; Published: 5 March 2018

\begin{abstract}
Cellulose nanocrystals (CNCs) are renewable nanosized materials with exceptional physicochemical properties that continue to garner a high level of attention in both industry and academia for their potential high-end material applications. These rod-shaped CNCs are appealing due to their non-toxic, carbohydrate-based chemical structure, large surface area, and the presence of ample surface hydroxyl groups for chemical surface modifications. CNCs, generally prepared from sulfuric acid-mediated hydrolysis of native cellulose, display an anionic surface that has been exploited for a number of applications. However, several recent studies showed the importance of CNCs' surface charge reversal towards the design of functional cationic CNCs. Cationization of CNCs could further open up other innovative applications, in particular, bioapplications such as gene and drug delivery, vaccine adjuvants, and tissue engineering. This mini-review focuses mainly on the recent covalent synthetic methods for the design and fabrication of cationic CNCs as well as their potential bioapplications.
\end{abstract}

Keywords: cellulose nanocrystals; cationic; synthesis; surface functionalization; applications

\section{Introduction}

\subsection{Cellulose and Cellulose Nanocrystals}

Cellulose, being one of the most abundant renewable natural polymers on earth, has been used for several years in both its unmodified and modified forms for the development of a range of materials and products useful for our society [1]. Chemically, cellulose is a linear long chain homopolysaccharide made up of $\beta$-D-anhydroglucopyranose units joined together by $\beta$-1,4-glycosidic bonds. The repeat unit consists of a dimer of glucose (cellobiose) with each monomer possessing one primary and two secondary hydroxyl groups (Figure 1).

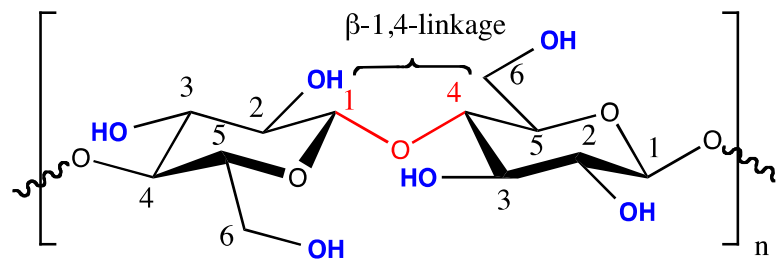

Figure 1. Chemical representation of a single cellulose chain repeat unit depicting two glucose units with a $\beta$-1,4-glycosidic linkage. 
Cellulose microfibrils are comprised of crystalline and amorphous regions and interestingly, when they are exposed to a combination of mechanical, chemical, and/or enzymatic conditions, highly crystalline regions can be extracted to afford rigid needle-like cellulose particles commonly termed as cellulose nanocrystals (CNCs) [2,3]. These rod-like cellulose particles have also been referred to in literature as nanowhiskers or nanocrystalline cellulose, however, for this review, they are all termed as CNCs. In general, CNCs can be isolated from almost any cellulosic materials and typical major sources include plants, bacteria, tunicates, and algae [4]. Despite being discovered as early as $1949[5,6]$, CNCs did not draw much attention until the works by Revol et al. on chiral nematic ordering of CNCs in aqueous suspension [7] and by Favier et al. on the use of CNCs as nanocomposite reinforcement [8,9]. Since then, CNCs have quickly attracted a high level of interest in the materials community due to their nanoscale dimensions (typically 50-3000 nm in length with cross-sections of 3-20 nm depending on the cellulosic sources and isolation experimental conditions) [2] and intrinsic physicochemical properties (high aspect ratio, unique optical, electrical, magnetic, and mechanical properties) [3,10-12]. The advent of nanotechnology and the growing importance of nanomaterials have further spurred research interests of CNCs in both academic and industrial sectors as evidenced by the influx in the number of scientific publications and patents related to CNCs in the past decades. Given CNCs' exceptional physical and chemical properties as well as future commercialization prospects, this recently led to their industrial production in North America, Japan, and Europe [13,14]. In addition to the production of CNCs at an affordable quantity, obtaining CNC batches with comparable sizes and properties [15] remains a top priority in order to meet the high demand of the CNC community for the design of multifunctional CNCs for commercial applications.

\subsection{Preparation of CNCs via Acid Hydrolysis of Native Cellulose}

Controlled acid-mediated hydrolysis of cellulose remains the typical chemical method for the synthesis of CNCs. During the acid hydrolysis step, the accessible amorphous regions are hydrolyzed to yield crystalline cellulose in the form of rod-shaped particles. Studies have indicated that the hydrolysis conditions (temperature, reaction times, acid concentration) and choice of acids are critical and can easily affect the particle dimensions, $\mathrm{CNCs}^{\prime}$ overall yield, and surface charge density [16-20]. While a number of acids such as hydrochloric acid [2,3], hydrobromic acid [21,22], phosphoric acid [23,24], and more recently, phosphotungstic acid [25] have been investigated, sulfuric acid remains the most commonly employed acid for the hydrolysis of cellulose raw materials in both academia and industry [3]. Sulfuric-acid-mediated hydrolysis of cellulose will also incorporate anionic sulfate half-ester $\left(\mathrm{OSO}_{3}{ }^{-}\right)$groups on the surface of the nanocrystals (Scheme 1) providing electrostatic stabilization in aqueous solutions [18,26]. The sulfate half-ester content is generally obtained by analyzing the amount of sulfur present by elemental analysis or via a much simpler method such as conductometric titration [27]. While the number of sulfate half-ester groups depends on the concentration of sulfuric acid and the hydrolysis time, the exact location of the $\mathrm{OSO}_{3}{ }^{-}$groups on the nanocrystals is still unknown [23].

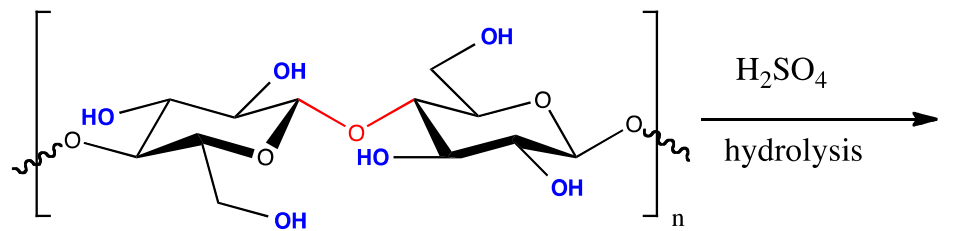

(a)

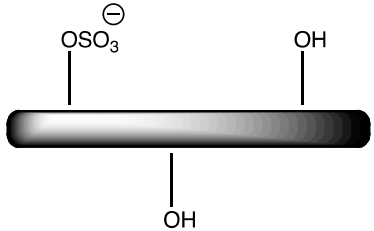

(b)

Scheme 1. Preparation of sulfated cellulose nanocrystals (CNCs) via acid hydrolysis of cellulose ((a) native cellulose; (b) diagrammatic representation of rod-like sulfated CNCs). 


\subsection{Surface Covalent Functionalization of CNCs}

Surface covalent modification of CNCs remains a popular area of research in literature for the design of advanced and multifunctional CNCs for a number of applications [2,28-30]. The presence of numerous hydroxyl groups $\left(8.13 \times 10^{-3} \mathrm{mmolm}^{-2}\right.$ for the number of hydroxyl groups per unit surface area of cotton CNCs [31]) allows the fine tuning of the surface of CNCs by imparting new properties to the material for the intended application. However, it is crucial to make sure no damage to the original morphology of the nanocrystals occurs during the surface functionalization process and as such, mild chemical methods are required to maintain the integrity of the nanocrystals. A number of surface covalent functionalizations of CNCs has been reported and some common examples include oxidation (tetramethylpiperidinyloxyl radical (TEMPO) oxidation for conversion of the primary hydroxyl groups to carboxylic acids [32] and periodate oxidation of vicinal diols to afford dialdehyde functionalities [33]), esterification [34,35], amidation [36,37], carbamation [38,39], amine functionalized CNCs (conversion of hydroxyl group to a terminated primary amine group) [40,41], radical polymerization [42-45], etherification, and other chemical modifications [2,29]. Readers are directed to a more detailed and critical review by Eyley and Thielemans on surface modifications of CNCs [29]. While most surface covalent functionalization methods of CNCs have allowed the introduction of the desired functionalities such as anionic charge, hydrophobicity, and fluorescence [46], recent studies have shown that cationization of CNCs might open up more opportunities for the design of cationic functional CNCs. Moreover, the intrinsically negative surface charge of CNCs generated by sulfuric-acid-mediated hydrolysis prevents the direct use of electrostatic interactions for the binding or self-assembly with negatively charged biomacromolecules, nucleic acids, and certain proteins [47]. Naturally derived cationic CNCs are attractive targets for potential gene and drug delivery, tissue engineering, and other therapeutic applications as they are generally non-toxic, biocompatible, and renewable. Hence, the development of new chemical methods for cationization of CNCs via surface functionalization is desirable (Scheme 2). Herein, we provide an overview on the design and fabrication of cationic CNCs through covalent surface functionalization methods as well as the potential applications of functional cationic CNCs.

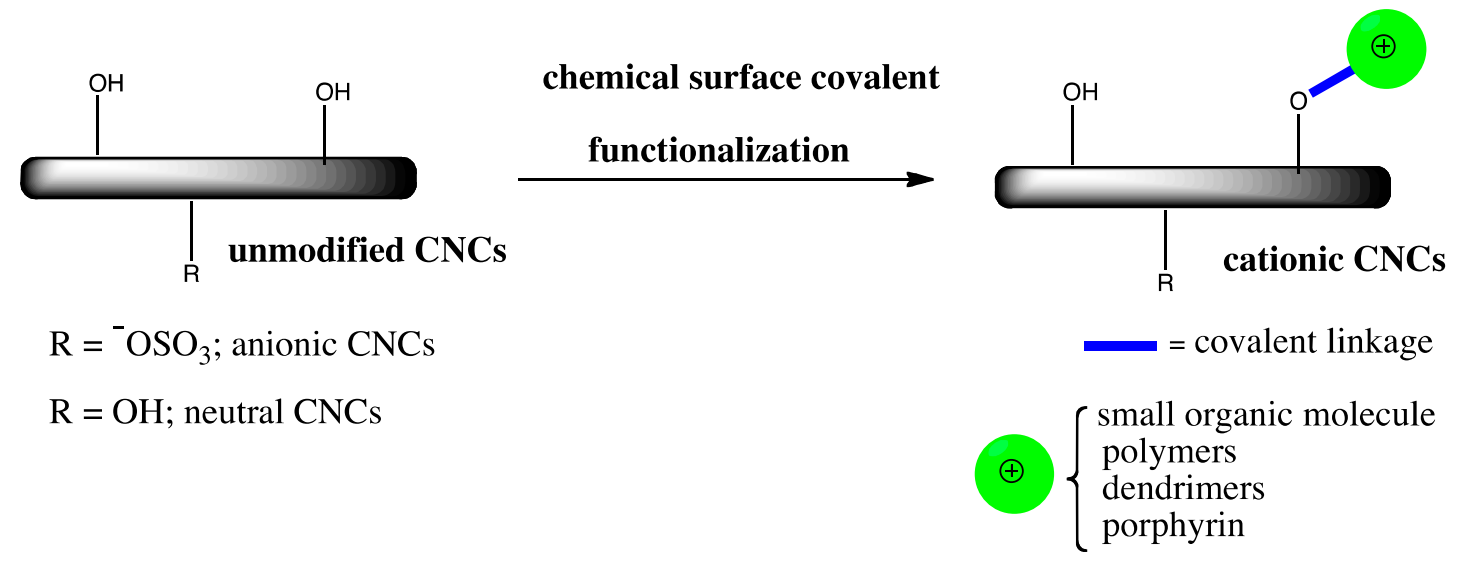

Scheme 2. Design of cationic rod-like CNCs via chemical surface covalent functionalization of unmodified CNCs.

\section{Surface Covalent Functionalization Methods for the Fabrication of Cationic CNCs}

\subsection{Surface Cationization of CNCS via Etherification Reaction}

The first cationic surface covalent functionalization of CNCs was reported by Hasani and co-workers, which involved an etherification reaction of CNCs (synthesized by hydrolysis of cotton filter aid using $64 \% w / w$ sulfuric acid at $45^{\circ} \mathrm{C}$ ) with (2,3-epoxypropyl) trimethylammonium chloride 
(EPTMAC) as cationization agent under basic conditions at $65^{\circ} \mathrm{C}$ [48]. Surface cationization proceeded via a nucleophilic addition reaction of the $\mathrm{CNCs}$ activated hydroxyl groups with the reactive epoxy functional group of EPTMAC (Scheme 3). The base $(7 \% w / v \mathrm{NaOH})$ is required for the activation of the hydroxyl groups as well as for cleavage of the sulfate half-ester groups in order to ensure the pure cationic nature of the resulting hydroxypropyltrimethylammonium chloride CNCs. Purification of the cationic CNCs required extensive dialysis for 15 days and sonication to afford stable aqueous cationic CNCs suspension. The success of the cationization was confirmed by electrophoretic mobility measurements which indicated a charge reversal from $-39 \pm 3 \mathrm{mV}$ to $+30 \pm 5 \mathrm{mV}$ upon reaction with EPTMAC. Surface properties of the cationic CNCs were analyzed by conductometric titrations to assess the trimethylammonium chloride content $\left(0.112 \mathrm{mmol} \mathrm{g}^{-1}\right.$ for a degree of substitution of 0.02 per bulk anhydroglucose unit) and atomic force microscopy for nanocrystals dimensions $(11 \pm 2 \mathrm{~nm} \times 174 \pm 18 \mathrm{~nm})$. While the morphology of the nanocrystals was not affected by surface modification, a decrease in total surface charge density of the cationic CNCs was observed.

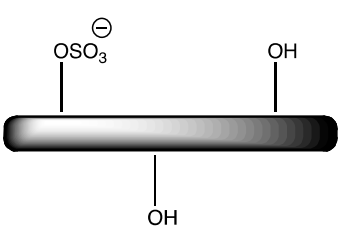

sulfated anionic CNCs

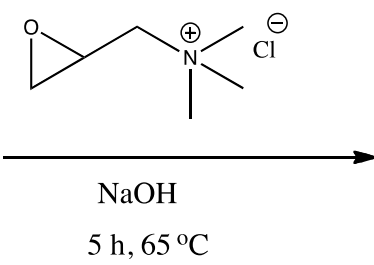

h, $65^{\circ} \mathrm{C}$

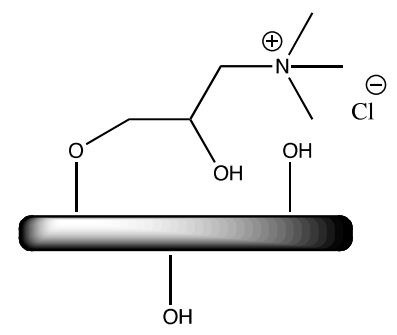

cationic CNCs

Scheme 3. Surface cationization of CNCs via a nucleophilic ring-opening of the epoxide moiety. (Adapted from reference [48] with permission from the Royal Society of Chemistry, copyright 2008).

In order to circumvent the issue of a low total surface charge density of the above cationized CNCs, Zaman and co-workers proposed an aqueous semi-dry method using a similar synthetic strategy as depicted in Scheme 3 [49]. In their study, dried sulfated CNCs were ground with powdered $\mathrm{NaOH}$, then mixed with the solvent $\left(\mathrm{H}_{2} \mathrm{O}\right.$ or $\mathrm{H}_{2} \mathrm{O}$ /DMSO mixture at different volume ratios) followed by dropwise addition of the EPTMAC. The impact of the amount of water on the cationization efficiency was thoroughly studied. In the presence of a high water content, a likely side-reaction such as alkaline hydrolysis of EPTMAC could occur (Scheme 4), thereby consuming the key reagent for the desired etherification reaction [50]. Although surface cationization of CNCs by the semi-dry process proceeded with an increase in the surface charge density over the unmodified CNCs, no X-ray diffraction (XRD) data was reported to assess any loss in crystallinity and the associated structural integrity of the nanocrystals [29].
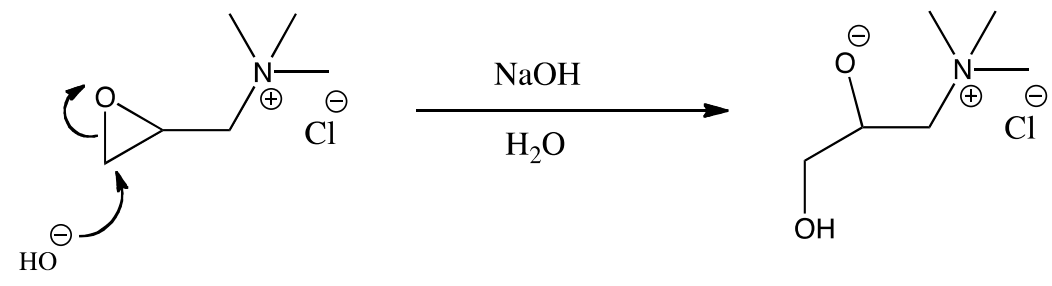

Scheme 4. Mechanism of alkaline hydrolysis of EPTMAC.

Lin and co-workers reported the same etherification reaction (as depicted in Scheme 3) to prepare cationic $\mathrm{CNCs}$ for the subsequent electrostatic binding with anionic alginate towards the design of biocompatible double-membrane hydrogel as complexing drug carriers [51]. Surface cationization of sulfated CNCs was also achieved non-covalently by physical adsorption with cationic branched 
polyethylenimine (Scheme 5). Cationic CNCs derived from the surface covalent chemical modification had a remarkable effect to sustain the drug release in the hydrogel in contrast to cationic CNCs prepared from the physical modification method. This further highlights the importance of surface covalent cationization which provides a strong permanent layer of cationic charges.

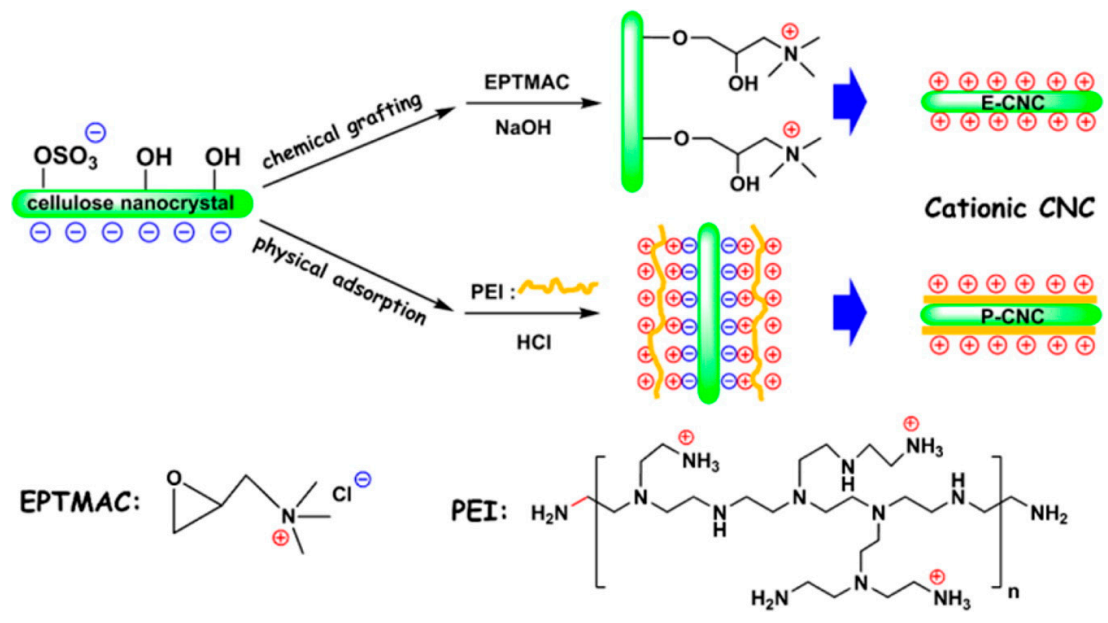

Scheme 5. Synthetic route for the preparation of cationic CNCs by chemical grafting and physical adsorption (Reproduced from reference [51] with permission from the American Chemical Society, copyright 2016).

In a recent study, You and co-workers designed nanocomposite injectable hydrogels based on quaternized cellulose and cationic CNCs [52]. The cationic CNCs were synthesized via an etherification reaction of anionic sulfated $\mathrm{CNCs}$ with 3-chloro-2-hydroxypropyl-trimethylammonium chloride (CHPTAC) under alkaline conditions at $65{ }^{\circ} \mathrm{C}$. The CHPTAC actually formed the epoxide which then reacted with the surface-activated alkoxide CNCs. The cationic CNCs behaved as physical fillers as well as components that could be cross-linked along with quaternized cellulose chains to form the matrix. The resulting hydrogel has improved mechanical strength, degradation, and sustained release behaviour of doxorubicin. These cationic CNC-based injectable hydrogels could be used for the sustained delivery of anticancer drugs. In other studies, cationic CNCs synthesized by employing EPTMAC as a cationization agent were used as miniemulsion polymerization stabilizers [53] and high performance nanocomposite films [54].

\subsection{Cationic Porphyrin-Based CNCs with Photobactericidal Activity}

Feese et al. reported the preparation of cationic CNCs that was surface-modified with a cationic porphyrin [55]. The porphyrin was covalently conjugated onto the CNCs' surface via the powerful Huisgen 1,3-dipolar cycloaddition reaction (Click chemistry). This Click reaction involves the coupling of an azide with a terminal alkyne to link two molecules via the formation of the stable 1,2,3-triazole ring [56,57]. The CNCs used in this study were obtained by HBr hydrolysis of cotton fibers (Whatman $\# 1$ filter paper, $98 \% \alpha$-cellulose, $80 \%$ crystallinity) at $100{ }^{\circ} \mathrm{C}$. The primary hydroxyl groups of CNCs were first transformed to tosylates (-OTs) leaving groups for subsequent $\mathrm{S}_{\mathrm{N}}{ }^{2}$ displacement with nucleophilic azide groups using sodium azide in dimethylformamide to afford surface reactive azidated CNCs (Scheme 6). While no data was provided on the degree of tosylation, the azidation occurred with a degree of substitution of 0.14 based on elemental analysis data. The next step in the synthesis involved the appendage of the cationic porphyrin unit on the surface of the CNCs under Click reaction conditions to chemically join the ethyne-bearing porphyrin to the azidated CNCs. The purified insoluble green cationic CNCs were obtained after isolation by several careful washes and centrifugations to remove unreacted materials and the copper catalyst [58] followed by freeze-drying of the aqueous suspensions. Proof of covalent conjugation between the cationic porphyrin and CNCs was confirmed using infrared 
spectroscopy (a decrease in the intensity of the azide band at $2113 \mathrm{~cm}^{-1}$ and an increase in $\mathrm{C}=\mathrm{N}$ band intensity at $1651 \mathrm{~cm}^{-1}$ originating from the porphyrin and triazole linkage) and diffusion NMR spectroscopy, and supported by thermogravimetric analysis and gel permeation chromatography. While the presence of the porphyrin fragments on the surface of the CNCs is an indication of the cationic nature of the modified CNCs, the success of the surface cationization was not further confirmed by electrophoretic mobility measurements.

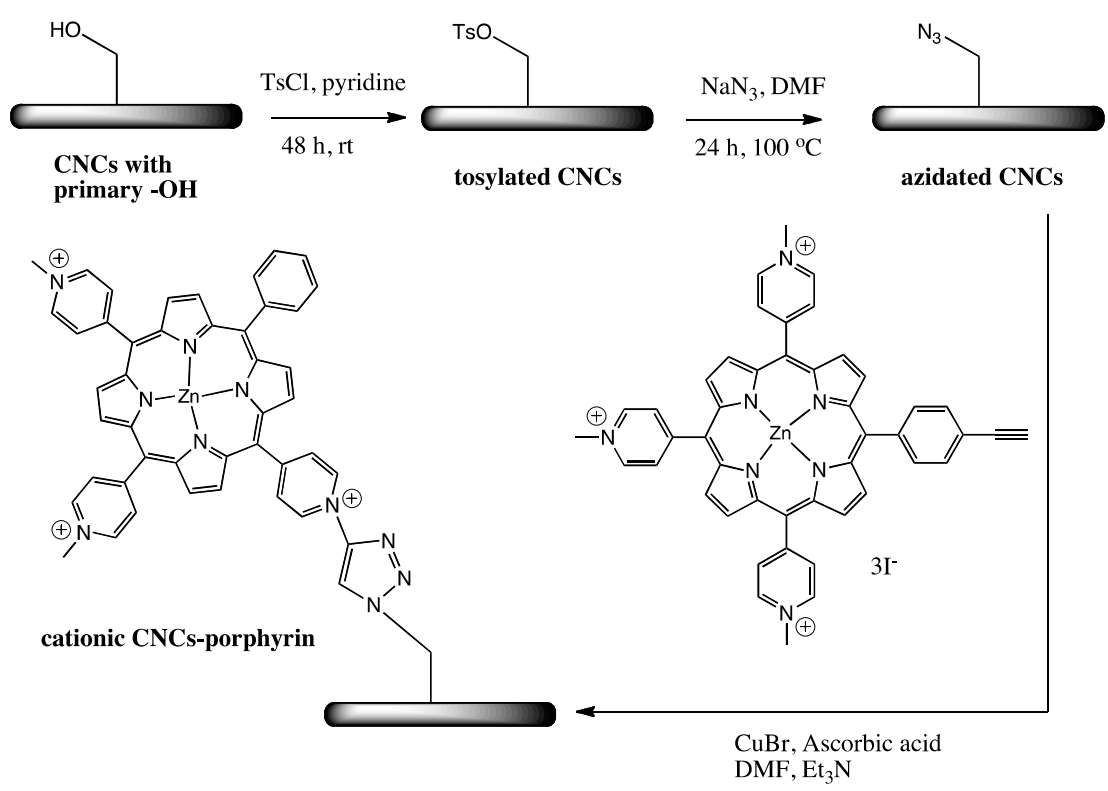

Scheme 6. Preparation of cationic porphyrin-based CNCs via Click chemistry. (Adapted from reference [55] with permission from the American Chemical Society, copyright 2011).

The ability of the synthesized cationic CNCs to photoinactivate genera of bacteria such as Staphylococcus aureus (Gram-positive), Escherichia coli (Gram-negative), and Mycobacterium smegmatis (mycobacterium) were investigated. Results indicated that the cationic CNCs displayed excellent activity toward the photodynamic inactivation of Mycobacterium smegmatis and Staphylococcus aureus, and minimum efficacy against Escherichia coli. Overall, this synthetic strategy exploits the benefits of CNCs as biodegradable, biocompatible, and renewable nanobiomaterial for the appendage of photosensitizers that could be potentially useful in the food preparation and health care industries.

\subsection{Cationic Imidazolium and Pyridinium Grafted CNCs}

Eyley and Thielemans designed cationic CNCs in a three-step synthetic strategy using the robust Click chemistry to append imidazolium cations on the surface of CNCs (obtained by $64 \mathrm{wt} \%$ sulfuric acid hydrolysis of bleached cotton) [59]. Chlorination of the primary hydroxyl groups with thionyl chloride was first achieved followed by reaction with sodium azide to afford surface-reactive azidated CNCs. Although the tosylate is a better leaving group than the chloride, chlorination was preferred over tosylation as the first step of the synthesis due to prior inconsistent results of heterogeneous tosylation reaction on cotton [60,61]. The ionic liquid 1-methyl-3-propargylimidazolium bromide ([MPIM][Br]) [62] was then reacted with the azidated CNCs under Click reaction conditions to generate the desired cationic imidazolium grafted CNCs (Scheme 7). The presence of the imidazolium fragments on the surface of the CNCs was confirmed by infrared spectroscopy and X-ray photoelectron spectroscopy (XPS). Using nitrogen concentration by elemental analysis, a degree of substitution of 0.36 was calculated for the grafting of the imidazolium, however, the extent of surface modification for the azidation step was not reported. The zeta-potential of the imidazolium-grafted CNCs was found to be $+47 \mathrm{mV}(v / \mathrm{s}-9.49 \mathrm{mV}$ for unmodified $\mathrm{CNCs})$, thereby indicating a cationic surface 
(surface charge density of $1.17 \mathrm{enm}$ ). Examining the crystallinity of the products at each stage of the surface functionalization is crucial to ensure no damage to the nanocrystals' structure and properties. The authors were able to successfully monitor the crystallinity of each product using powder X-ray diffraction (XRD) technique. A constant value of the crystallinity index at each stage of the surface modifications was observed except for a slight decrease from 0.89 to 0.80 for the chlorination step. Furthermore, it was possible to exchange the bromide anion with bistriflimide and the monoanionic orange II dye, thereby allowing the design of a number of ion exchange systems or catalysts using $\mathrm{CNCs}$ as a support template.

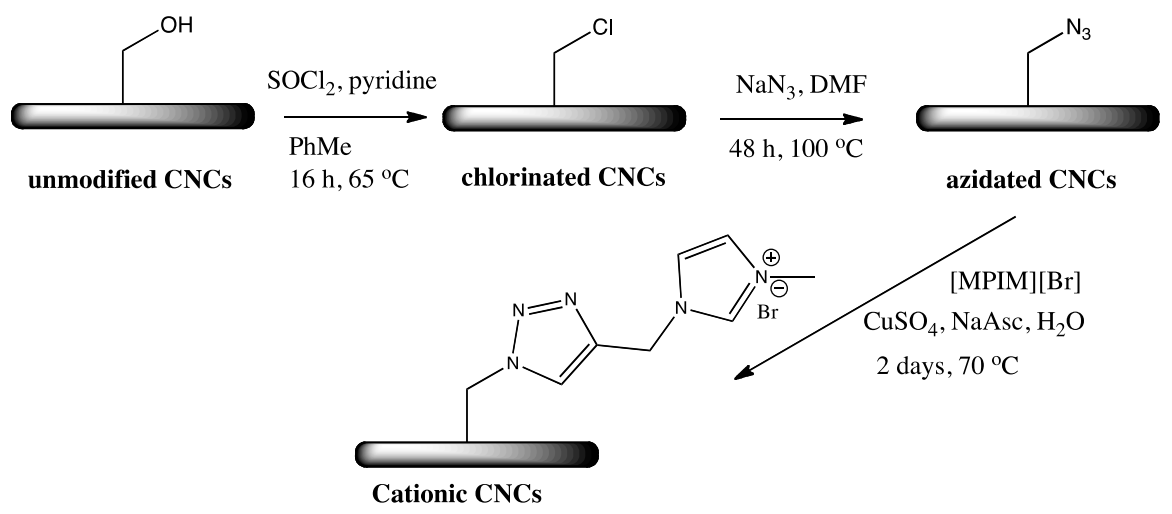

Scheme 7. Synthesis of imidazolium grafted CNCs via Click chemistry. (Adapted from reference [59] with permission from the Royal Society of Chemistry, copyright 2011).

In a further attempt to decrease the number of synthetic steps and make the synthetic design more amenable for potential industrial applications, the Thielemans group also developed a simple and heterogeneous one-pot synthetic route for the preparation of cationic pyridinium-grafted CNCs [63]. Unmodified CNCs were treated with 4-(bromomethyl)- or 4-(1-bromoethyl)benzoic acid in the presence of $p$-toluenesulfonyl chloride and pyridine to append the cationic pyridinium groups on the CNCs' surface (Scheme 8 ). The grafting involves an esterification reaction between the activated 4-(1-bromoethyl/bromomethyl) benzoic acid as their mixed anhydrides and CNCs and a nucleophilic substitution of the bromide with pyridine (pyridine alkylation type reaction). Purification of the resulting cationic $\mathrm{CNCs}$ was achieved by Soxhlet extraction with dichloromethane and ethanol for $24 \mathrm{~h}$ to get rid of any unbound reactants.
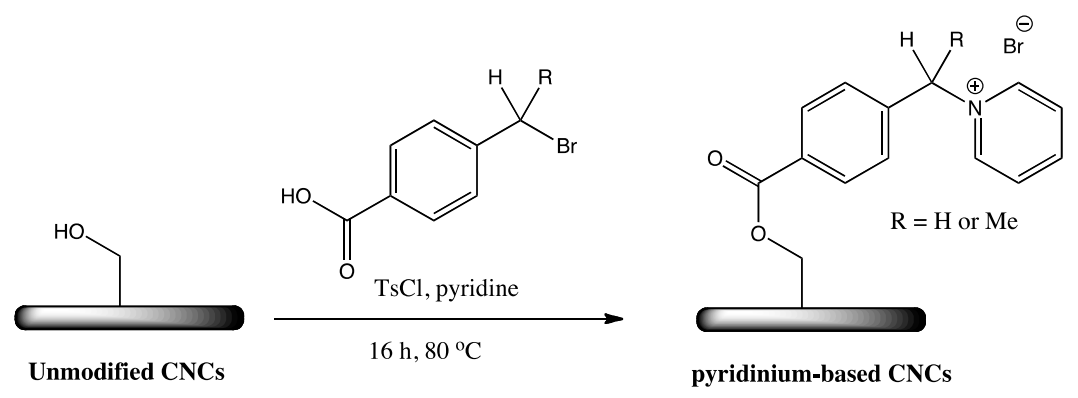

Scheme 8. One-pot synthetic route for the design of pyridinium-grafted CNCs. (Adapted from reference [63] with permission from the Royal Society of Chemistry, copyright 2013).

The success of the surface covalent grafting was confirmed by IR spectroscopy (the presence of the typical carbonyl stretching peak of the ester functionality at $\sim 1720 \mathrm{~cm}^{-1}$ ) and XPS (appearance of new nitrogen peaks at $402.1 \mathrm{eV}$ ). Surface cationization was also elucidated by zeta potential measurements which indicated a change of $-33.6 \mathrm{mV}$ for unmodified CNCs to +54.5 and $+59.0 \mathrm{mV}$ 
for benzyl and $\alpha$-methylbenzyl pyridinium CNCs respectively. The morphology and crystallinity of the pyridinium-based CNCs were unaffected as shown by XRD and atomic force microscopy (AFM) results. The absorption of the Orange II dye on the surface of the cationized CNCs was also demonstrated. The degree of substitution on the surface of the CNCs was determined to be 0.38 and 1.10 for benzyl and $\alpha$-methylbenzyl pyridinium CNCs, respectively, based on nitrogen content from elemental analysis. A higher degree of substitution was surprisingly observed for $\alpha$-methylbenzyl pyridinium CNCs which the authors attributed possibly to the difference in relative solubilities of the two pyridinium salts in the reaction medium. The solubility issues of the pyridinium salts were later addressed in another work by performing the one-pot cationization reaction at higher dilution [64]. The resulting highly charged cationic CNCs were found to be excellent flocculants for freshwater microalgae harvesting. Recently, the same group exploited this one-pot synthetic method given the high grafting density to expand on the design of cationic CNCs with varying properties [65] (Figure 2). Two different structural amines, 1-methylimidazole and 4-dimethylaminopyridine, were employed in this study, which also acted as the catalytic base for the esterification step as well as the nucleophile to attack the electrophilic carbon of the $\mathrm{C}-\mathrm{Br}$ and generate the cationic charge. Overall, their study demonstrated the ability to vary the type of cation on the surface of CNCs, which could be applied in the field of drug delivery or the sequestration of contaminants from waste water streams.
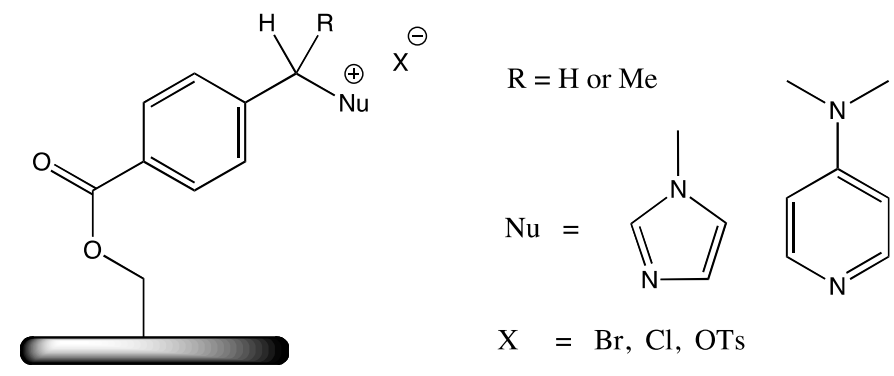

$\mathrm{X}=\mathrm{Br}, \mathrm{Cl}$, OTs

Figure 2. Chemical structures of cationic 1-methylimidazolium and 4-dimethylaminopyridinium grafted CNCs. Adapted from reference [65] with permission from Springer Nature, copyright 2016).

\subsection{Cationic CNCs via Polymerization Techniques}

The development of living radical polymerization (LRP) or reversible deactivation radical polymerization techniques has allowed materials scientists to synthesize polymers with well-defined properties and controlled molecular architectures. The main LRP techniques include atom transfer radical polymerization (ATRP), reversible addition fragmentation chain transfer (RAFT), and nitroxide-mediated polymerization (NMP), which have been exploited for the modification of polysaccharides towards the formation of high-performance hybrids [66,67]. These LRP techniques have also been employed on the surface of colloidal CNCs for the grafting of several functional polymer brushes with tunable or stimuli-responsive properties [42-45,68-71]. Surface-initiated atom transfer radical polymerization (SI-ATRP) and single-electron transfer living radical polymerization (SI-SET-LRP) are the most widely used methods for grafting from of polymers on the surface of CNCs. Poly $(N, N$-dimethylaminoethyl methacrylate) (P(DMAEMA)) is one of the popular and well-studied stimuli-responsive polymer systems that possess both $\mathrm{pH}$ and thermoresponsive properties [72,73]. $\mathrm{P}$ (DMAEMA) is a weak polyelectrolyte (pKa of $\sim 7.4$ at room temperature) and below its $\mathrm{pKa}$, PDMAEMA chains are positively charged due to the protonation of the pendant dimethylamino groups [74]. P(DMAEMA) was grafted onto the surface of CNCs using the free radical polymerization method in the presence of ammonium persulfate as the water-soluble initiator (Scheme 9) [75]. Cationization of the CNCs' surface was demonstrated at $\mathrm{pH} 3.0$ with a zeta potential of $+40 \mathrm{mV}$. The impact of the resulting PDMAEMA-grafted CNCs on the stability of Pickering emulsions was studied. It was found that PDMAEMA chains could tune the stability of emulsion droplets by manipulating $\mathrm{pH}$ and temperature for the design of dual-responsive emulsion systems. 


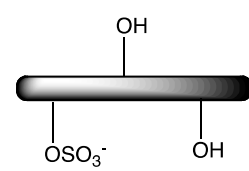

sulfated CNCs

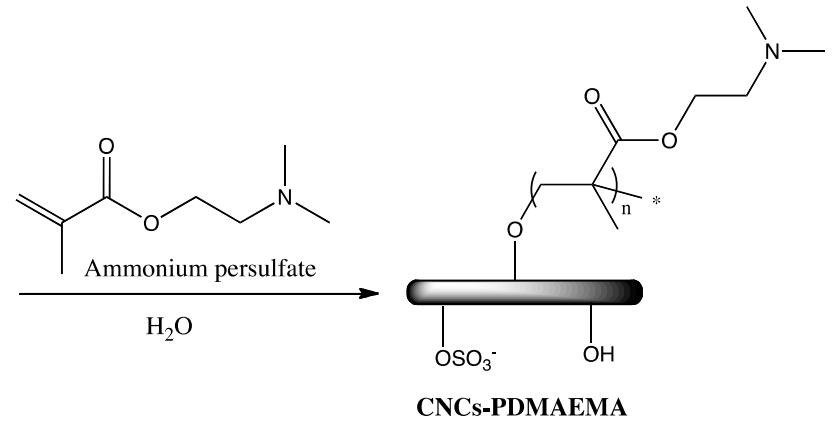

Scheme 9. Preparation of CNCs grafted PDMAEMA via free radical polymerization. (Adapted from reference [75] with permission from the American Chemical Society, copyright 2014).

In a recent study, Rosilo and co-workers developed an efficient method for shielding the anionic sulfate half-esters of CNCs using SI-ATRP as the key step to introduce poly P(DMAEMA) brushes on the surface of CNCs [47]. Pristine CNCs were first modified with initiator molecules via the chemical vapor deposition (CVD) method to form CNC macroinitiators with high-density initiator sites for subsequent grafting of $\mathrm{P}(\mathrm{DMAEMA})$ in dry DMF at $70{ }^{\circ} \mathrm{C}$ in the presence of ethyl $\alpha$-bromoisobutyryl bromide $(\mathrm{EBiB})$ as the sacrificial initiator. Cationization occurred when the polymer brush-modified CNC-g-P(DMAEMA) was further quaternized with methyl iodide in pure water (Scheme 10).
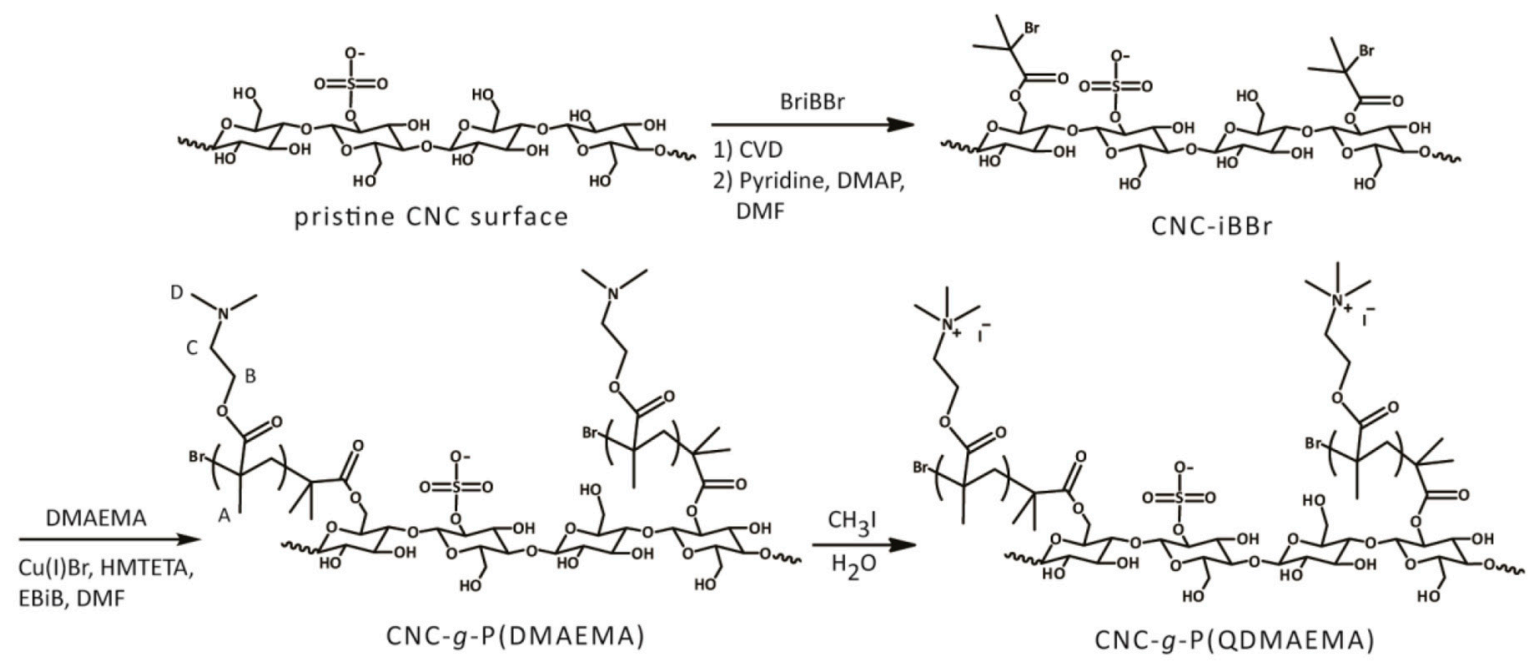

Scheme 10. Preparation of cationic polymer brush surface-modified CNCs (Reproduced from reference [47] with permission from the Royal Society of Chemistry, copyright 2014).

The resulting cationized CNCs displayed excellent dispersibility and colloidal stability in water with a zeta potential of $+38 \mathrm{mV}$. Given the cationic nature of the surface-modified CNCs, the ability to bind with virus particles possessing negatively charged outer surfaces was investigated. Gel electrophoresis, dynamic light scattering, and transmission electron microscopy (TEM) (Figure 3) results showed the electrostatic binding of cationic CNCs with cowpea chlorotic mottle virus (CCMV) and norovirus-like particles (NoV-VLP) with large affinities at different salt concentrations. This synthetic approach for the design of cationic CNCs and the virus-binding study concept could be applied to other viruses or anionic materials such as synthetic nanoparticles, DNA, and bacteria for improving viral delivery of therapeutic agents.

PDMAEMA was reported to effectively condense plasmid DNA into nanoparticles to aid cellular internalization for gene delivery applications [76,77]. Taking advantage of this property, $\mathrm{Hu}$ and co-workers designed cationic CNC-based gene vectors by wrapping the surface of CNCs with 
disulphide bond-linked dense PDMAEMA brushes [78]. Prior to SI-ATRP with PDMAEMA, sulfated CNCs were modified in two steps: (i) reaction of cystamine with CDI-activated CNCs to afford CNCs-SS-NH $\mathrm{NH}_{2}$ (ii) amidation reaction of CNC-SS-NH $\mathrm{N}_{2}$ with $\alpha$-bromoisobutyric acid (BIBA) to generate bromoisobutylryl-terminated CNCs (CNC-SS-Br) (Figure 4). The resulting CNC-graft-PDMAEMA vectors (CNC-SS-PD) were evaluated for their gene condensation abilities, reduction sensitivities, cytotoxicities, gene transfection efficiencies, cellular uptake, and the in vitro and in vivo antitumor effects. The release of plasmid DNA was achieved by degrading the disulphide linkage under reducing conditions. Low cytotoxicities, high transfection efficiencies, and good activity in inhibiting the growth of tumors and cancer cells rendered the rod-like CNCs with biocleavable PDMAEMA side-chains as good candidates for gene/drug delivery systems.
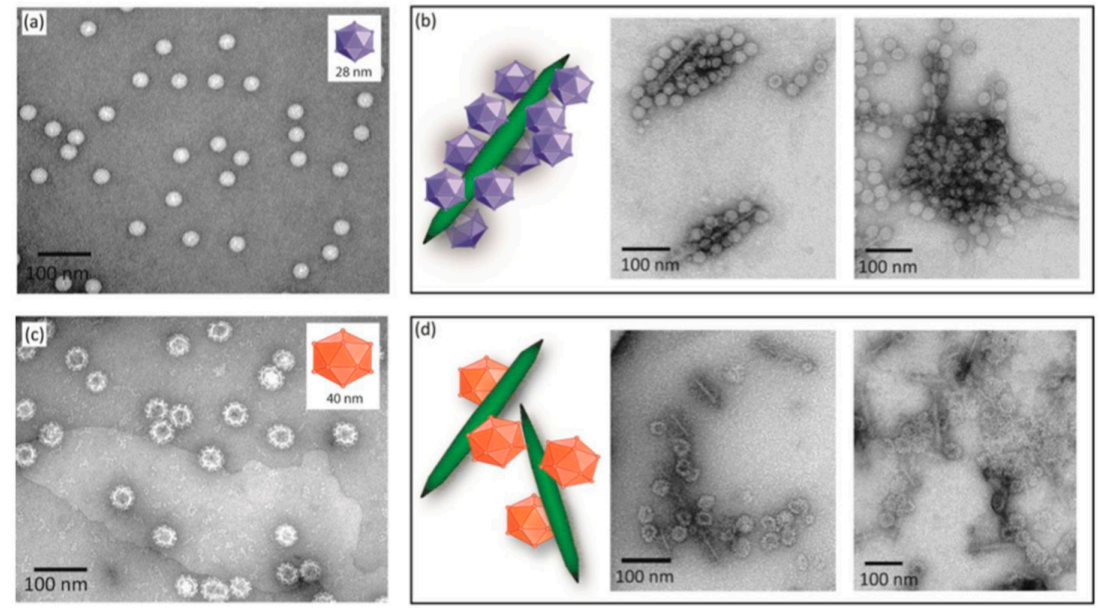

Figure 3. TEM images of (a) CCMV viruses in water; (b) Complexes of CNC-g-P(QDMAEMA) and CCMV in water; (c) NoV-VLP in $500 \mathrm{mM} \mathrm{NaCl}$ stock solution; (d) Complexes of CNC-g-P(QDMAEMA) and NoV-VLP at $200 \mathrm{mM} \mathrm{NaCl}$. (Reproduced from reference [47] with permission from the Royal Society of Chemistry, copyright 2014).

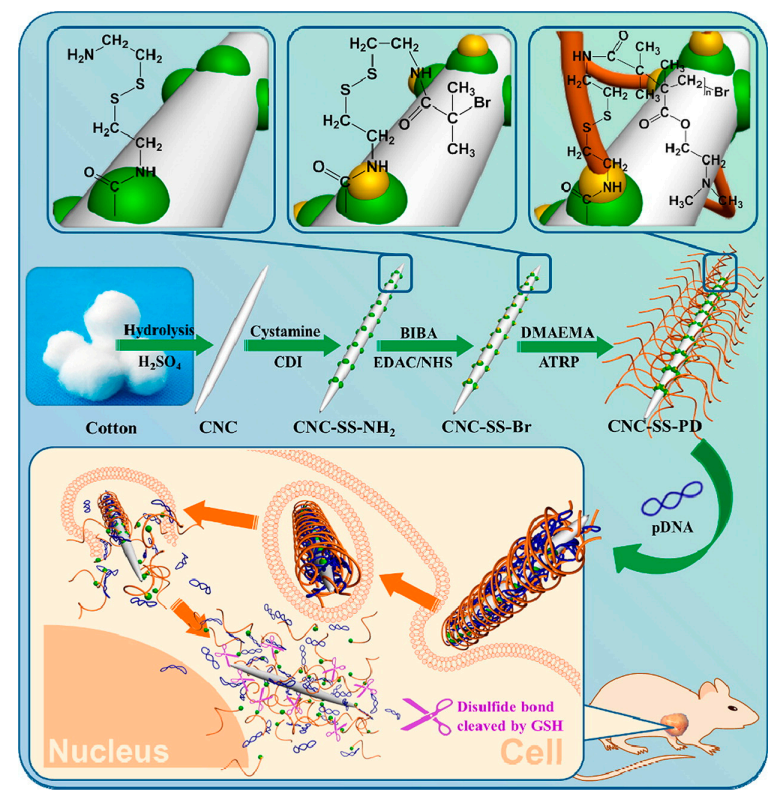

Figure 4. Schematic diagram depicting the synthesis of CNC-graft-PDMAEMA (CNC-SS-PD) via SI-ATRP and the gene delivery process. (Reproduced from reference [78] with permission from the American Chemical Society, copyright 2015). 
Kan and co-workers disclosed a facile one-pot aqueous ceric ion-initiated graft polymerization of 4-vinylpyridine from the surface hydroxyl of CNCs for the design of biodegradable $\mathrm{pH}$ responsive flocculants (Scheme 11) [69]. Ceric (IV) ammonium nitrate (CAN) was used as the initiator and interestingly, this one-pot polymerization method did not require a pre-polymerization step to covalently attach initiators on the surface of CNCs. Sonication was required throughout the reaction to prevent aggregation and ensure a good dispersion of $\mathrm{CNCs}$ for an efficient polymerization process. The radical polymerization gave poly (4-vinylpyridine)-grafted CNCs (P4VP-g-CNCs), which had a positive electrophoretic mobility at $\mathrm{pH}<5$ due to the cationic surface. P4VP-g-CNCs changed character from cationic to anionic and hydrophilic to hydrophobic with an increase in $\mathrm{pH}$ (Scheme 11). The reversible flocculating nature of $\mathrm{P} 4 \mathrm{VP}-\mathrm{g}$-CNCs could potentially be used as flocculating agents in paper and pulp manufacturing industries.
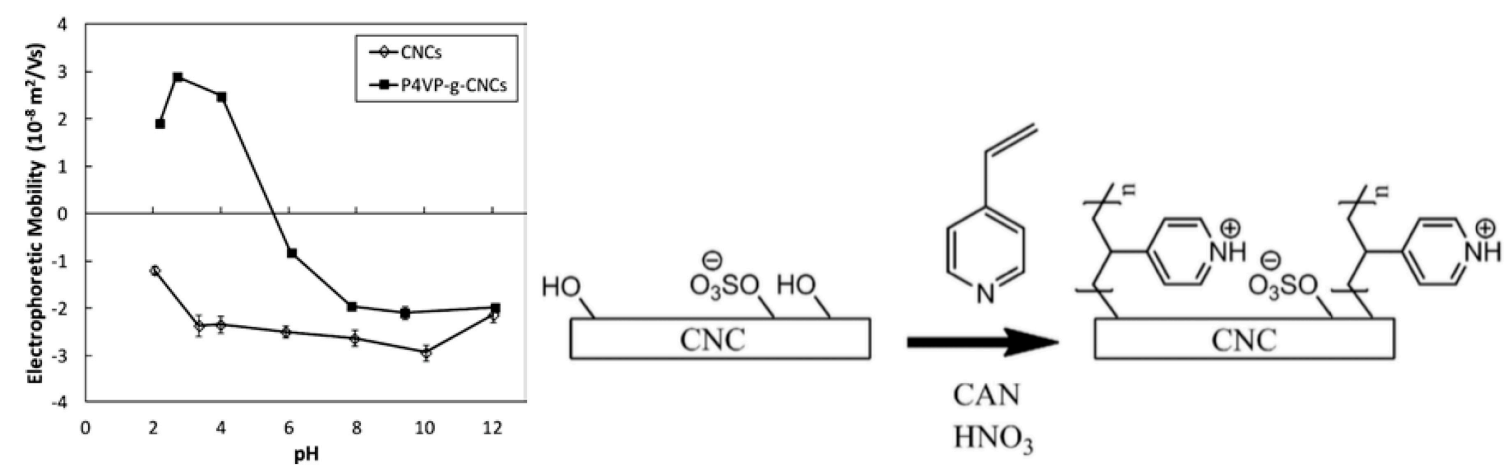

Scheme 11. One-pot aqueous ceric ion surface-initiated graft polymerization of 4-vinylpyidine with sulfated CNCs and the effect of $\mathrm{pH}$ on the electrophoretic mobility of unmodified CNCs and P4VP-g-CNCs (Adapted from reference [69] with permission from the American Chemical Society, copyright 2013).

SI-SET-LRP is a robust and versatile copper (0)-mediated living radical polymerization technique for the design of multifunctional materials with complex macromolecular architectures $[79,80]$. Compared to other living radical polymerization methods, SET-LRP is simple to conduct and it occurs at ambient temperature or below with fast polymerization rates. Metal catalyst removal is quite challenging in other polymerization techniques as residual metal can impede the direct use of the product in many applications. SET-LRP overcomes the above limitation with the use of parts per million levels of catalyst as well as simple catalyst removal from the reaction mixture. Recently, Hemraz and co-workers used the SI-SET-LRP technique to covalently decorate cationic poly(2-aminoethylmethacrylate) (poly(AEM)) and poly(N-(2-aminoethylmethacrylamide) (poly(AEMA)) on CNCs' surface [45]. Surface hydroxyl groups of sulfated CNCs were esterified using 2-bromoisobutyryl bromide in dry THF at room temperature in the presence of triethylamine as base and catalytic DMAP. The amount of initiator sites on the cellulosic surface was varied by reacting CNCs with 2-bromoisobutyryl bromide at different ratios with respect to the anhydroglucose unit. The obtained initiator-modified CNCs underwent SI-SET-LRP with the cationic monomers (AEM, AEMA), copper (I) bromide, and $N, N, N^{\prime}, N^{\prime \prime}, N^{\prime \prime}$-pentamethyldiethylenetriamine (PMDETA) in a 1:1 water/methanol mixture at room temperature (Scheme 12).

The surface of the CNCs was rendered cationic as indicated by zeta potential measurements. The cationic nature was further confirmed by gold deposition as evidenced by scanning transmission electron microscopy (STEM) images (Figure 5). The in-vitro toxicity of these cationic CNCs was analyzed using a 3-(4,5-dimethylthiazol-2-yl)-2,5-diphenyltetrazolium bromide (MTT) assay in two different cell lines, J774A1 (mouse monocyte cells), and MCF-7 (human breast adenocarcinoma cells). These studies showed that none of the tested cationic-modified CNCs decreased cell viability at low 
concentrations. Given the needle-like structure of $\mathrm{CNCs}$, further studies showed that one of the cationic CNCs displayed immunogenic properties that perhaps could be used as vaccine adjuvants [81].

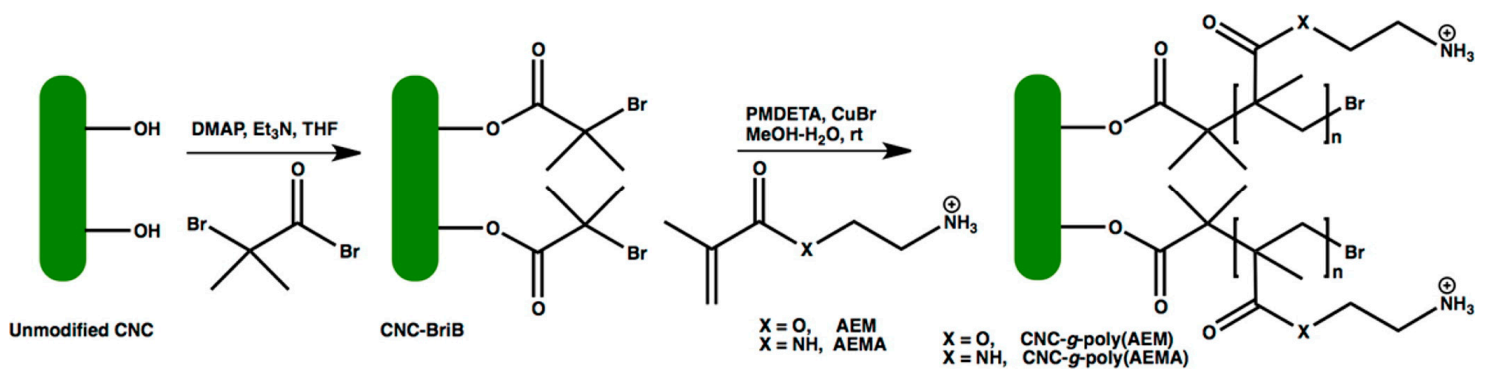

Scheme 12. Synthetic pathway for the preparation of cationic CNCs via SI-SET-LRP (Reproduced from reference [45] with permission from the American Chemical Society, copyright 2015).

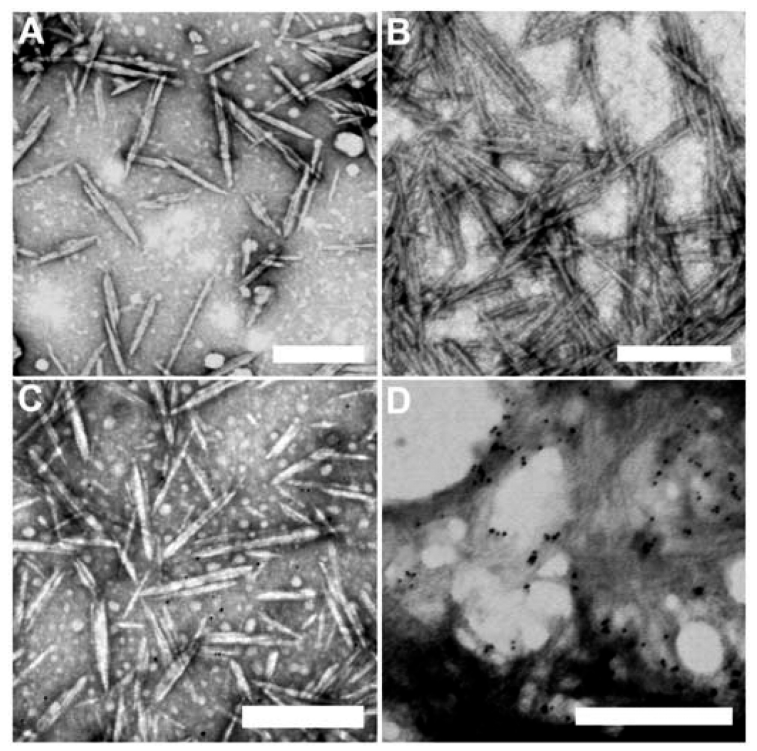

Figure 5. STEM images of unmodified CNCs and cationic CNCs-g-poly(AEMA)-1 before (A,B) and after (C,D) gold deposition, respectively. (Reproduced from reference [45] with permission from the American Chemical Society, copyright 2015).

Using a combination of UV-induced photopolymerization and living cationic ring-opening polymerization, Hou and co-workers prepared biocompatible poly(2-oxazoline)s with a defined bottle brush architecture on CNCs [82]. The synthesis proceeded first via a self-initiated photografting and photopolymerization of 2-isopropenyl-2-oxazoline (IPOx), which led to the direct formation of poly(2-isopropenyl-2-oxazoline) (PIPOx) brushes on the CNCs (Scheme 13). Upon reaction with methyl triflate, the PIPOx brushes were transformed to polyoxazolinium brushes. Surface-initiated living ring-opening polymerization of 2-alkyl-2-oxazoline monomers and subsequent addition of piperidine afforded the cationic side chains of poly(2-oxazoline)s on the CNCs. Thermogravimetric analysis of the poly(2-oxazoline)-modified CNCs showed an improved thermal stability and no change in crystalline structure as indicated by XRD experiment. Taking advantage of the cationic nature of the side chain terminal piperidinium of the bottle brush, indocyanine green (ICG) was successfully immobilized via electrostatic interactions. Overall, cationic poly(2-oxazoline)-modified CNCs could be potential candidates for photothermal cancer therapy. 


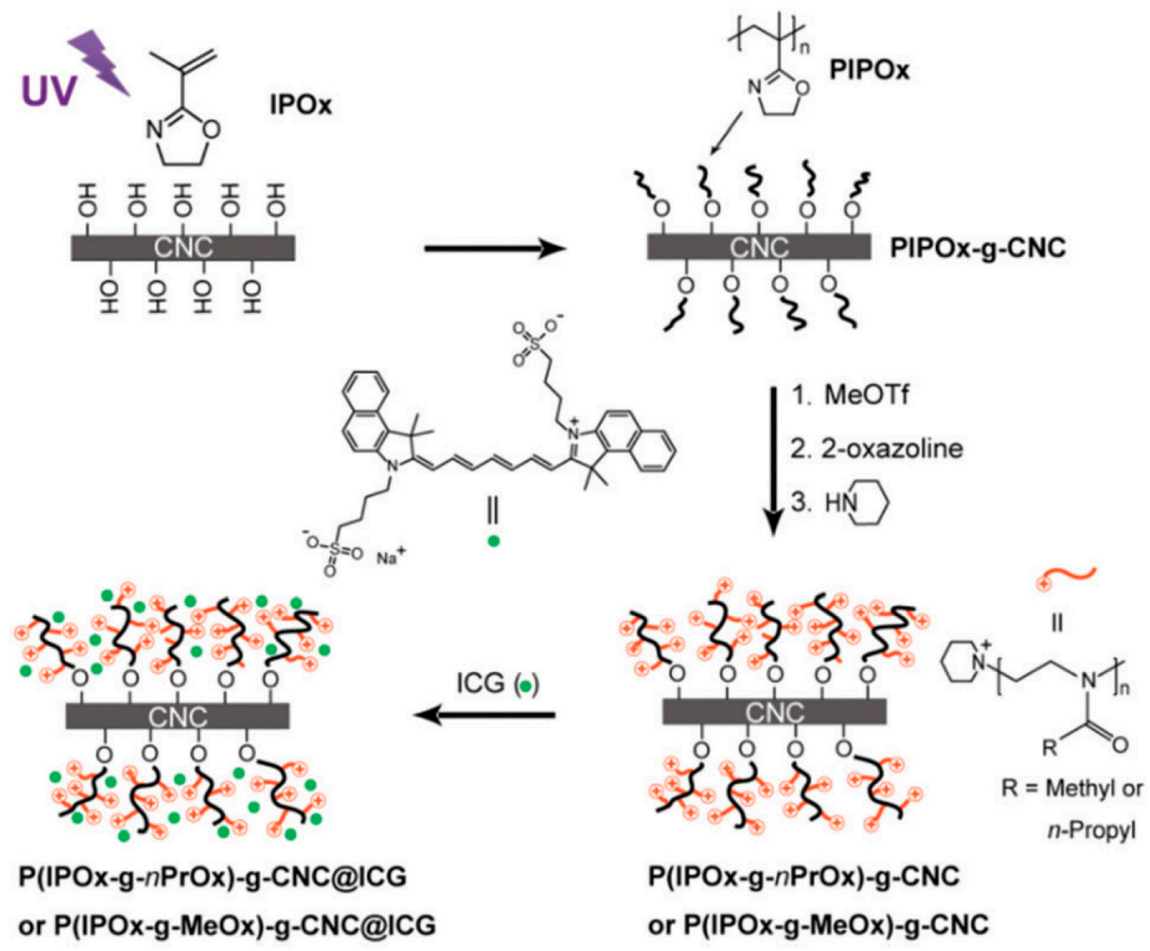

Scheme 13. Preparation of poly(2-oxazoline)-modified CNCs using UV-induced photopolymerization and living cationic ring-opening polymerization and subsequent immobilization of indocyanine green (ICG) via electrostatic interactions (Reproduced from reference [82] with permission from the Royal Society of Chemistry, copyright 2017).

\subsection{Other Covalent Cationization Synthetic Methods}

\subsubsection{Cationization of CNCs via Grafting of Cationic Hyperbranched Dendrimers}

Dendrimers are highly branched or hyperbranched globular nanosized macromolecules defined by three main building blocks, namely an interior dendritic structure, a central core, and an exterior surface with functional surface groups. Dendrimers can be prepared with their size, molar masses, number of end groups, and compositions being precisely controlled and thus their unique features make them attractive candidates for biomedical and industrial applications [83,84]. Dendronized polymers are formed when the dendritic segments are densely grafted along a linear polymer [85]. The design of dendronized-based hybrid material is appealing in order to combine unique features of both materials. For instance, dendronized polymers based on polyamidoamine (PAMAM) and chitosan (a natural cationic organic polymer) as the core were synthesized and used as a biocompatible gene delivery vector [86]. In line with this concept, Tehrani and Basiryan were able to covalently graft PAMAM up to three generations on the surface of CNCs by a divergent method [87]. The synthetic route involved several steps starting with tosylation of unmodified CNCs followed by nucleophilic displacement with ethylenediamime to afford aminated CNCs. The aminated CNCs underwent a Michael addition reaction of the amino groups to methylacrylate and amidation of the obtained terminal ester groups with ethylenediamine gave the desired CNCs-grafted PAMAM. Reactions were repeated to construct a G3 CNC-grafted PAMAM that grew on the surface of the rod-like CNCs (Figure 6).

Covalent grafting of the cationic hyperbranched dendritic PAMAM was confirmed by IR and ${ }^{1}$ HNMR spectroscopies. A positive zeta potential $(+25 \mathrm{mV})$ was obtained and interestingly, after the denderonization process, small globular residues covering the surface of the CNCs were identified by AFM, which is a good indication of the presence of grafted PAMAM. AFM results also showed 
that the morphology of the CNCs was preserved, however, no XRD data was given to confirm if such extensive covalent surface functionalization involving several synthetic steps had led to a loss of crystallinity and structural integrity of the modified CNCs.

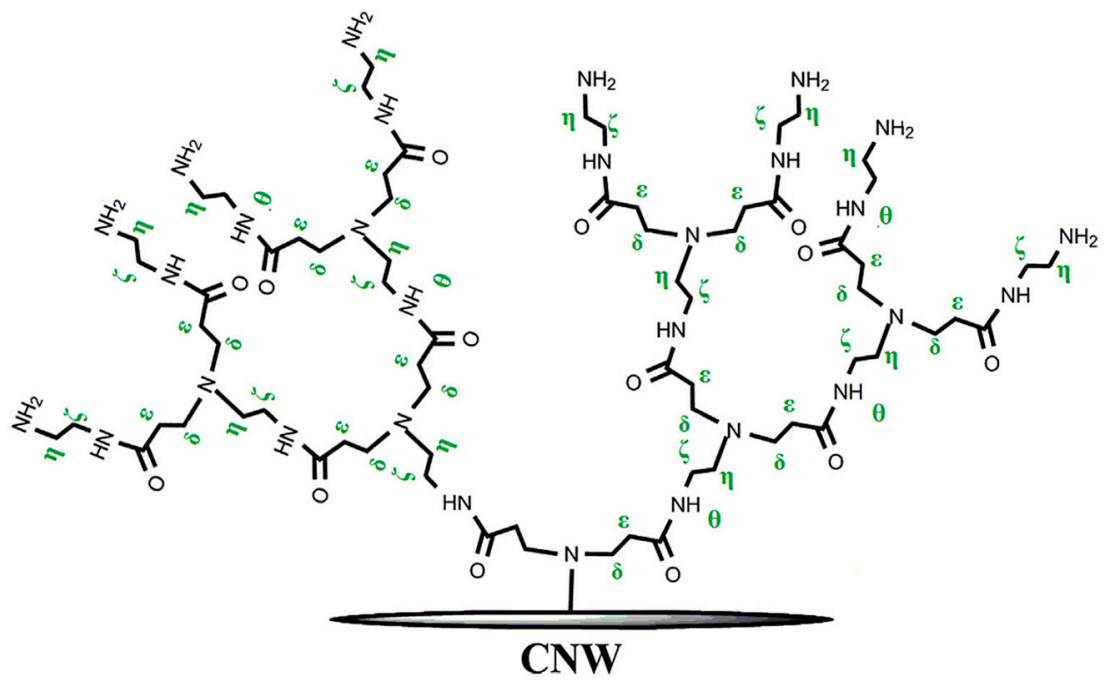

Figure 6. Chemical structure of G3 CNC-grafted PAMAM (Adapted from reference [87] with permission from Elsevier, copyright 2015).

\subsubsection{Cationic CNCs as siRNA Delivery Agents}

The search for an effective siRNA delivery agent endowed with low toxicity and high transfection efficiency still remains a challenge in the field of siRNA delivery for the treatment of several diseases [88]. Other than viruses, cationic polymers, peptides and nanoparticles, and biopolymers such as chitosan, curdlan, hyaluronic acid, or pullulan were also investigated as siRNA delivery agents [89-92]. The rod-like nature of CNCs made them attractive bionanomaterials for gene delivery since rod-like nanoparticles were shown to be more rapidly internalized than spherical ones [93] and had a significant impact on gene transfection [94]. Recently, cationic CNCs were designed for complexing with siRNA via electrostatic interactions [95]. Anionic CNCs were first oxidized by sodium periodate in the presence of propan-1-ol to avoid cellulose super-oxidation and formed aldehyde functionalities that underwent a reductive amination reaction with polyethyleimine (PEI, $600 \mathrm{Da}$ ) and sodium cyanoborohydride as the reducing agent. Covalent conjugation of CNCs with PEI was confirmed by IR spectroscopy and a change of zeta potential from $-40.0 \mathrm{mV}$ (oxidized CNCs) to $+36.9 \mathrm{mV}$. Chemically modified CNCs retained the crystal structure of native cellulose as indicated by $\mathrm{XRD}$ analysis of the $\mathrm{CNC}$ s for each chemical surface functionalization in the synthetic design. Cationic CNCs-PEI were loaded with siRNA to generate CNCs-PEI-siRNA particles strongly stabilized by ionic interactions. The ionic complexation was confirmed by UV absorption measurements and cellular uptake of these particles was monitored by ethidium bromide staining. In addition to having a lack of cytotoxicity, CNCs-PEI also protected siRNA from degradation and favored its delivery into the cell cytoplasm. Overall, this first study showed that cationic CNCs-PEI are promising nanocarriers for siRNA killer delivery to induce apoptosis in vitro. However, in vivo studies are still required to realize the full potential of the cationic CNCs-PEI as efficient siRNA non-viral vectors.

\section{Conclusions}

The unique physico-chemical properties of CNCs led to an extensive investigation of this rod-like bionanomaterial for many diverse applications. The presence of ample surface hydroxyl groups becomes an ideal platform for covalent surface functionalization of CNCs. The design of cationic $\mathrm{CNCs}$ started to gain interest in the CNC community in the past decade given their potential 
use as flocculating and photobactericidal agents, templates for ion-exchange systems or catalyst, dual-responsive emulsion systems, vaccine adjuvants, photothermal cancer therapy, and drug and gene delivery vectors. Various synthetic approaches were utilized to covalently attach cationic moieties such as small organic molecules, polymers, porphyrin, and dendrimers. Etherification and polymerization reactions are by far the popular synthetic approaches for the design of cationic CNCs. The one-pot synthetic strategy is promising since there is less chance of destroying the morphology and integrity of the nanocrystals when compared to multi-step synthetic pathways. Thorough characterization of the modified CNCs at each stage of the synthetic modification process is highly recommended to ensure reproducibility and high quality of the synthesized cationic CNCs. Detailed in vivo studies are still required to fully explore the use of cationic CNCs for potential bioapplications. Overall, we expect to see more novel synthetic methods in the future for the design of functional cationic CNCs.

Acknowledgments: Rajesh Sunasee gratefully acknowledges funding from the SUNY Plattsburgh Presidential Research Award.

Conflicts of Interest: The authors declare no conflict of interest.

\section{References}

1. Klemm, D.; Heublein, B.; Fink, H.P.; Bohn, A. Cellulose: Fascinating Biopolymer and Sustainable Raw Material. Angew. Chem. Int. Ed. 2005, 44, 3358-3393. [CrossRef] [PubMed]

2. Moon, R.J.; Martini, A.; Nairn, J.; Simonsen, J.; Youngblood, J. Cellulose nanomaterials review: Structure, properties and nanocomposites. Chem. Soc. Rev. 2011, 40, 3941-3994. [CrossRef] [PubMed]

3. Habibi, Y.; Lucia, L.A.; Rojas, O.J. Cellulose nanocrystals: Chemistry, self-assembly, and applications. Chem. Rev. 2010, 110, 3479-3500. [CrossRef] [PubMed]

4. Brinchi, L.; Cotana, F.; Fortunati, E.; Kenny, J.M. Production of nanocrystalline cellulose from lignocellulosic biomass: Technology and applications. Carbohydr. Polym. 2013, 94, 154-169. [CrossRef] [PubMed]

5. Ranby, B.G. Aqueous colloidal solutions of cellulose micelles. Acta Chem. Scand. 1949, 3, 649-650. [CrossRef]

6. Ranby, B.G.; Ribi, E. Uber Den Feinbau Zellulose. Experientia 1950, 6, 12-14. [CrossRef] [PubMed]

7. Revol, J.F.; Bradford, H.; Giasson, J.; Marchessault, R.H.; Gray, D.G. Helicoidal self-ordering of cellulose microfibrils in aqueous suspension. Int. J. Biol. Macromol. 1992, 14, 170-172. [CrossRef]

8. Favier, V.; Chanzy, H.; Cavaillé, J.Y. Polymer nanocomposites reinforced by cellulose whiskers. Macromolecules 1995, 28, 6365-6367. [CrossRef]

9. Favier, V.; Canova, G.R.; Cavaillé, J.Y.; Chanzy, H.; Dufresne, A.; Gauthier, C. Nanocomposites materials from latex and cellulose whiskers. Polym. Adv. Technol. 1995, 6, 351-355. [CrossRef]

10. Domingues, R.M.A.; Gomes, M.E.; Reis, R.L. The potential of cellulose nanocrystals in tissue engineering strategies. Biomacromolecules 2014, 15, 2327-2346. [CrossRef] [PubMed]

11. Peng, B.L.; Dhar, N.; Liu, H.L.; Tam, K.C. Chemistry and applications of nanocrystalline cellulose and its derivatives: A nanotechnology perspective. Can. J. Chem. Eng. 2011, 89, 1191-1206. [CrossRef]

12. Sunasee, R.; Hemraz, U.D.; Ckless, K. Cellulose nanocrystals: A versatile nanoplatform for emerging biomedical applications. Expert Opin. Drug Deliv. 2016, 13, 1243-1256. [CrossRef] [PubMed]

13. Future Markets Inc. The Global Market for Nanocellulose to 2020; Future Markets Inc.: Edinburgh, UK, 2013.

14. Microfibrillar cellulose project from borregaard gets EU funding. BioPlastics Magazine. 27 April 2016. Available online: http:/ / www.bioplasticsmagazine.com/en/news/meldungen/20160427-Microfibrillarcellulose-project-from-Borregaard-gets-EU-funding--.php (accessed on 1 February 2018).

15. Reid, M.S.; Villalobos, M.; Cranston, E.D. Benchmarking cellulose nanocrystals: From the laboratory to industrial production. Langmuir 2017, 33, 1583-1598. [CrossRef] [PubMed]

16. Hamad, W.Y.; Hu, T.Q. Structure-process-yield interrelations in nanocrystalline cellulose extraction. Can. J. Chem. Eng. 2010, 88, 392-402. [CrossRef]

17. Chen, L.; Wang, Q.; Hirth, K.; Baez, C.; Agarwal, U.P.; Zhu, J.Y. Tailoring the yield and characteristics of wood cellulose nanocrystals (CNC) using concentrated acid hydrolysis. Cellulose 2015, 22, 1753-1762. [CrossRef]

18. Dong, X.M.; Revol, J.-F.; Gray, D.G. Effect of microscystallite preparation conditions on the formation of colloid crystals of cellulose. Cellulose 1998, 5, 19-32. [CrossRef] 
19. Beck-Candanedo, S.; Roman, M.; Gray, D.G. Effect of reaction conditions on the properties and behavior of wood cellulose nanocrystal suspensions. Biomacromolecules 2005, 6, 1048-1054. [CrossRef] [PubMed]

20. Dong, S.; Bortner, M.J.; Roman, M. Analysis of the sulfuric acid hydrolysis of wood pulp for cellulose nanocrystal production: A central composite design study. Ind. Crops Prod. 2016, 93, 76-87. [CrossRef]

21. Filpponen, I.; Argyropoulos, D.S. Regular linking of cellulose nanocrystals via click chemistry: Synthesis and formation of cellulose nanoplatelet gels. Biomacromolecules 2010, 11, 1060-1066. [CrossRef] [PubMed]

22. Sadeghifar, H.; Filpponen, I.; Clarke, S.P.; Broughman, F.; Argyropoulos, D.S. Production of cellulose nanocrystals using hydrobromic acid and click reactions on their surface. J. Mater. Sci. 2011, 46, 7344-7355. [CrossRef]

23. Lemke, C.H.; Dong, R.Y.; Michal, C.A.; Hamad, W.Y. New insights into nano-crystalline cellulose structure and morphology based on solid-state NMR. Cellulose 2012, 19, 1619-1629. [CrossRef]

24. Espinosa, S.C.; Kuhnt, T.; Foster, E.J.; Weder, C. Isolation of thermally stable cellulose nanocrystals by phosphoric acid hydrolysis. Biomacromolecules 2013, 14, 1223-1230. [CrossRef] [PubMed]

25. Lu, Q.; Cai, Z.; Lin, F.; Tang, L.; Wang, S.; Huang, B. Extraction of cellulose nanocrystals with a high yield of $88 \%$ by simultaneous mechanochemical activation and phosphotungstic acid hydrolysis. ACS Sustain. Chem. Eng. 2016, 4, 2165-2172. [CrossRef]

26. Roman, M.; Winter, W.T. Effect of Sulfate Groups from Sulfuric Acid Hydrolysis on the Thermal Degradation Behavior of Bacterial Cellulose. Biomacromolecules 2004, 5, 1671-1677. [CrossRef] [PubMed]

27. Beck, S.; Méthot, M.; Bouchard, J. General procedure for determining cellulose nanocrystal sulfate half-ester content by conductometric titration. Cellulose 2015, 22, 101-116. [CrossRef]

28. Dufresne, A. Nanocellulose: A new ageless bionanomaterial. Mater. Today 2013, 16, 220-227. [CrossRef]

29. Eyley, S.; Thielemans, W. Surface modification of cellulose nanocrystals. Nanoscale 2014, 6, 7764-7779. [CrossRef] [PubMed]

30. Hemraz, U.D.; Sunasee, R. Functionalization of Nanocrystalline Cellulose Surfaces. In Dekker Encyclopedia of Nanoscience and Nanotechnology, 3rd ed.; Lyshevski, S.E., Ed.; CRC Press: Boca Raton, FL, USA, 2014; Volume II.

31. Lin, N.; Dufresne, A. Surface chemistry, morphological analysis and properties of cellulose nanocrystals with gradiented sulfation degrees. Nanoscale 2016, 6, 5384-5393. [CrossRef] [PubMed]

32. Habibi, Y.; Chanzy, H.; Vignon, M.R. Tempo-mediated surface oxidation of cellulose whiskers. Cellulose 2006, 13, 679-687. [CrossRef]

33. Sun, B.; Hou, Q.; Liu, Z.; Ni, Y. Sodium periodate oxidation of cellulose nanocrystal and its application as a paper wet strength additive. Cellulose 2015, 22, 1135-1146. [CrossRef]

34. Braun, B.; Dorgan, J.R. Single-Step Method for the Isolation and Surface Functionalization of Cellulosic Nanowhiskers. Biomacromolecules 2009, 10, 334-341. [CrossRef] [PubMed]

35. Avila Ramirez, J.A.; Fortunati, E.; Kenny, J.M.; Torre, L.; Foresti, M.L. Simple citric acid-catalyzed surface esterification of cellulose nanocrystals. Carbohydr. Polym. 2017, 157, 1358-1364. [CrossRef] [PubMed]

36. Araki, J.; Wada, M.; Kuga, S. Steric stabilization of a cellulose microcrystal suspension by poly(ethylene glycol) grafting. Langmuir 2001, 17, 21-27. [CrossRef]

37. Azzam, F.; Heux, L.; Putaux, J.-L.; Jean, B. Preparation by grafting onto, characterization, and properties of thermally responsive polymer-decorated cellulose nanocrystals. Biomacromolecules 2010, 11, 3652-3659. [CrossRef] [PubMed]

38. Habibi, Y.; Dufresne, A. Highly filled bionanocomposites from functionalized polysaccharide nanocrystals. Biomacromolecules 2008, 9, 1974-1980. [CrossRef] [PubMed]

39. Zoppe, J.O.; Peresin, M.S.; Habibi, Y.; Venditti, R.A.; Rojas, O.J. Reinforcing poly(epsilon-caprolactone) nanofibers with cellulose nanocrystals. ACS Appl. Mater. Interfaces 2009, 1, 1996-2004. [CrossRef] [PubMed]

40. Akhlaghi, S.P.; Zaman, M.; Mohammed, N.; Brinatti, C.; Batmaz, R.; Berry, R.; Loh, W.; Tam, K.C. Synthesis of amine functionalized cellulose nanocrystals: Optimization and characterization. Carbohydr. Res. 2015, 409, 48-55. [CrossRef] [PubMed]

41. Hemraz, U.D.; Boluk, Y.; Sunasee, R. Amine-decorated nanocrystalline cellulose surfaces: Synthesis, characterization and surface properties. Can. J. Chem. 2013, 91, 974-981. [CrossRef]

42. Morandi, G.; Heath, L.; Thielemans, W. Cellulose nanocrystals grafted with polystyrene chains through surface-initiated atom transfer radical polymerization (ATRP). Langmuir 2009, 25, 8280-8286. [CrossRef] [PubMed] 
43. Zoppe, J.O.; Habibi, Y.; Rojas, O.J.; Venditti, R.A.; Johansson, L.S.; Efimenko, K.; Osterberg, M.; Laine, J. Poly(N-isopropylacrylamide) brushes grafted from cellulose nanocrystals via surface-initiated single-electron transfer living radical polymerization. Biomacromolecules 2010, 11, 2683-2691. [CrossRef] [PubMed]

44. Hemraz, U.D.; Lu, A.; Sunasee, R.; Boluk, Y. Structure of poly(N-isopropylacrylamide) brushes and steric stability of their grafted cellulose nanocrystal dispersions. J. Colloid Interface Sci. 2014, 430, 157-165. [CrossRef] [PubMed]

45. Hemraz, U.D.; Campbell, K.A.; Burdick, J.S.; Ckless, K.; Boluk, Y.; Sunasee, R. Cationic poly(2-aminoethylmethacrylate) and poly( $N$-(2-aminoethylmethacrylamide) modified cellulose nanocrystals: Synthesis, characterization, and cytotoxicity. Biomacromolecules 2015, 16, 319-325. [CrossRef] [PubMed]

46. Klemm, D.; Kramer, F.; Moritz, S.; Lindström, T.; Ankerfors, M.; Gray, D.; Dorris, A. Nanocelluloses: A new family of nature-based materials. Angew. Chem. Int. Ed. 2011, 50, 5438-5466. [CrossRef] [PubMed]

47. Rosilo, H.; McKee, J.R.; Kontturi, E.; Koho, T.; Hytönen, V.P.; Ikkala, O.; Kostiainen, M.A. Cationic Polymer Brush-Modified Cellulose Nanocrystals for High-Affinity Virus Binding. Nanoscale 2014, 6, 11871-11881. [CrossRef] [PubMed]

48. Hasani, M.; Cranston, E.D.; Westman, G.; Gray, D.G. Cationic surface functionalization of cellulose nanocrystals. Soft Matter 2008, 4, 2238-2244. [CrossRef]

49. Zaman, M.; Xiao, H.; Chibante, F.; Ni, Y. Synthesis and characterization of cationically modified nanocrystalline cellulose. Carbohydr. Polym. 2012, 89, 163-170. [CrossRef] [PubMed]

50. Rena, J.L.; Peng, F.; Sun, R.C.; Kennedy, J.F. Influence of hemicellulosic derivatives on the sulfate kraft pulp strength. Carbohydr. Polym. 2009, 75, 338-342. [CrossRef]

51. Lin, N.; Gèze, A.; Wouessidjewe, D.; Huang, J.; Dufresne, A. Biocompatible double-membrane hydrogels from cationic cellulose nanocrystals and anionic alginate as complexing drugs codelivery. ACS Appl. Mater. Interfaces 2016, 8, 6880-6889. [CrossRef] [PubMed]

52. You, J.; Cao, J.; Zhao, Y.; Zhang, L.; Zhou, J.; Chen, Y. Improved Mechanical Properties and Sustained Release Behavior of Cationic Cellulose Nanocrystals Reinforeced Cationic Cellulose Injectable Hydrogels. Biomacromolecules 2016, 17, 2839-2848. [CrossRef] [PubMed]

53. Kedzior, S.A.; Marway, H.S.; Cranston, E.D. Tailoring cellulose nanocrystal and surfactant behavior in miniemulsion polymerization. Macromolecules 2017, 50, 2645-2655. [CrossRef]

54. Li, M.-C.; Mei, C.; Xu, X.; Lee, S.; Wu, Q. Cationic surface modification of cellulose nanocrystals: Toward tailoring dispersion and interface in carboxymethyl cellulose films. Polymers 2016, 107, 200-210. [CrossRef]

55. Feese, E.; Sadeghifar, H.; Gracz, H.S.; Argyropoulos, D.S.; Ghiladi, R.A. Photobactericidal porphyrin-cellulose nanocrystals: Synthesis, characterization, and antimicrobial Properties. Biomacromolecules 2011, 12, 3528-3539. [CrossRef] [PubMed]

56. Rostovtsev, V.V.; Green, L.G.; Fokin, V.V.; Sharpless, K.B. A stepwise huisgen cycloaddition process: Copper(I)-catalyzed regioselective "ligation" of azides and terminal alkynes. Angew. Chem. Int. Ed. 2002, 41, 2596-2599. [CrossRef]

57. Tornoe, C.W.; Christensen, C.; Meldal, M. Peptidotriazoles on solid phase: [1,2,3]-triazoles by regiospecific copper(i)-catalyzed 1,3-dipolar cycloadditions of terminal alkynes to azides. J. Org. Chem. 2002, 67, 3057-3064. [CrossRef] [PubMed]

58. Agut, W.; Agnaou, R.; Lecommandoux, S.; Taton, D. Synthesis of block copolypeptides by click chemistry. Macromol. Rapid Commun. 2008, 29, 1147-1155. [CrossRef]

59. Eyley, S.; Thielemans, W. Imidazolium grafted cellulose nanocrystals for ion exchange applications. Chem. Commun. 2011, 47, 4177-4179. [CrossRef] [PubMed]

60. McCormick, C.L.; Dawsey, T.R.; Newman, J.K. Competitive formation of cellulose p-toluenesulfonate and chlorodeoxycellulose during homogeneous reaction of $p$-toluenesulfonyl chloride with cellulose in N,N-dimethylacetamide-lithium chloride. Carbohydr. Res. 1990, 208, 183-191. [CrossRef]

61. Liebert, T.; Hänsch, C.; Heinze, T. Click chemistry with polysaccharides. Macromol. Rapid Commun. 2006, 27, 208-213. [CrossRef]

62. Gao, Y.; Gao, H.; Piekarski, C.; Shreeve, J.M. Azolium salts functionalized with cyanomethyl, vinyl, or propargyl substituents and dicyanamide, dinitramide, perchlorate and nitrate anions. Eur. J. Inorg. Chem. 2007, 2007, 4965-4972. [CrossRef]

63. Jasmani, L.; Eyley, S.; Wallbridge, R.; Thielemans, W. A facile one-pot route to cationic cellulose nanocrystals. Nanoscale 2013, 5, 10207-10211. [CrossRef] [PubMed] 
64. Vandamme, D.; Eyley, S.; den Mooter, G.V.; Muylaert, K.; Thielemans, W. Highly charged cellulose-based nanocrystals as flocculants for harvesting Chlorella vulgaris. Bioresour. Technol. 2015, 194, 270-275. [CrossRef] [PubMed]

65. Jasmani, L.; Eyley, S.; Schütz, C.; Gorp, H.-V.; De Feyter, S.; Thielemans, W. One-pot functionalization of cellulose nanocrystals with various cationic groups. Cellulose 2016, 23, 3569-3576. [CrossRef]

66. Tizzotti, M.; Charlot, A.; Fleury, E.; Stenzel, M.; Bernard, J. Modification of polysaccharides through controlled/living radical polymerization grafting-Towards the generation of high performance hybrids. Macromol. Rapid Commun. 2010, 31, 1751-1772. [CrossRef] [PubMed]

67. Sunasee, R.; Narain, R. Glycopolymer syntheses. In Glycopolymers: Synthesis and Applications, 1st ed.; Narain, R., Ed.; Smithers Rapra: Shawbury, UK, 2014; pp. 1-44.

68. Habibi, Y. Key advances in the chemical modification of nanacelluloses. Chem. Soc. Rev. 2014, 43, 1519-1542. [CrossRef] [PubMed]

69. Kan, K.H.M.; Li, J.; Wijesekera, K.; Cranston, E.D. Polymer-grafted cellulose nanocrystals as pH-responsive reversible flocculants. Biomacromolecules 2013, 14, 3130-3139. [CrossRef] [PubMed]

70. Morandi, G.; Thielemans, W. Synthesis of cellulose nanocrystals bearing photocleavable grafts by ATRP. Polym. Chem. 2012, 3, 1402-1407. [CrossRef]

71. Roeder, R.D.; Garcia-Valdez, O.; Whitney, R.A.; Champagne, P.; Cunningham, M.F. Graft modification of cellulose nanocrystals via nitroxide-mediated polymerization. Polym. Chem. 2016, 7, 6383-6390. [CrossRef]

72. Saigal, T.; Dong, H.; Matyjaszewski, K.; Tilton, R.R.D. Pickering emulsions stabilized by nanoparticles with thermally responsive grafted polymer brushes. Langmuir 2010, 26, 15200-15209. [CrossRef] [PubMed]

73. Yao, Z.L.; Tam, K.C. Synthesis and self-assembly of stimuli-responsive poly(2-(dimethylamino) ethyl methacrylate)-block-fullerene (PDMAEMA-b-C60) and the demicellization induced by free PDMAEMA chains. Langmuir 2011, 27, 6668-6673. [CrossRef] [PubMed]

74. Rinkenauer, A.C.; Schallon, A.; Günther, U.; Wagner, M.; Betthausen, E.; Schubert, U.S.; Schacher, F.H. A Paradigm Change: Efficient Transfection of Human Leukemia Cells by Stimuli-Responsive Multicompartment Micelles. ACS Nano 2013, 7, 9621-9631. [CrossRef] [PubMed]

75. Tang, J.; Lee, M.F.X.; Zhang, W.; Zhao, B.; Berry, R.M.; Tam, K.C. Dual responsive pickering emulsion stabilized by poly[2-(dimethylamino)ethyl methacrylate] grafted cellulose nanocrystals. Biomacromolecules 2014, 15, 3052-3060. [CrossRef] [PubMed]

76. Hu, H.; Xiu, K.M.; Xu, S.L.; Yang, W.T.; Xu, F.J. Functionalized layered double hydroxide nanoparticles conjugated with disulfide-linked polycation brushes for advanced gene delivery. Bioconjug. Chem. 2013, 24, 968-978. [CrossRef] [PubMed]

77. Xu, F.J.; Yang, W.T. Polymer vectors via controlled/living radical polymerization for gene delivery. Prog. Polym. Sci. 2011, 36, 1099-1131. [CrossRef]

78. Hu, H.; Yuan, W.; Liu, F.-S.; Cheng, G.; Xu, F.-J.; Ma, J. Redox-responsive polycation-functionalized cotton cellulose nanocrystals for effective cancer treatment. ACS Appl. Mater. Interfaces 2015, 7, 8942-8951. [CrossRef] [PubMed]

79. Anastasaki, A.; Nikolaou, V.; Nurumbetov, G.; Wilson, P.; Kempe, K.; Quinn, J.F.; Davis, T.P.; Whittaker, M.R.; Haddleton, D.M. Cu(0)-Mediated Living Radical Polymerization: A Versatile Tool for Materials Synthesis. Chem. Rev. 2016, 116, 835-877. [CrossRef] [PubMed]

80. Lligadas, G.; Grama, S.; Percec, V. Recent developments in the synthesis of biomacromolecules and their conjugates by single electron transfer-living radical polymerization. Biomacromolecules 2017, 18, 1039-1063. [CrossRef] [PubMed]

81. Sunasee, R.; Araoye, E.; Pyram, D.; Hemraz, U.D.; Boluk, Y.; Ckless, K. Cellulose nanocrystal cationic derivative induces NLRP3 inflammasome-dependent IL-1 $\beta$ secretion associated with mitochondrial ROS production. Biochem. Biophys. Rep. 2015, 4, 1-9. [CrossRef]

82. Hou, L.; Fang, J.; Wang, W.; Xie, Z.; Dong, D.; Zhang, N. Indocyanine green-functionalized bottle brushes of poly(2-oxazoline) on cellulose nanocrystals for photothermal cancer therapy. J. Mater. Chem. B 2017, 5 , 3348-3354. [CrossRef]

83. Lee, C.C.; MacKay, J.A.; Frechet, J.M.; Szoka, F.C. Designing dendrimers for biological applications. Nat. Biotechnol. 2005, 23, 1517-1526. [CrossRef] [PubMed]

84. Satija, J.; Gupta, U.; Jain, N.K. Pharmaceutical and biomedical potential of surface engineered dendrimers. Crit. Rev. Ther. Drug Carrier Syst. 2007, 24, 257-306. [CrossRef] [PubMed] 
85. Schlüter, A.D.; Rabe, J.P. Dendronized polymers: Synthesis, characterization, assembly at Interfaces, and manipulation. Angew. Chem. Int. Ed. 2000, 39, 864-883. [CrossRef]

86. Deng, J.; Zhou, Y.; Xu, B.; Mai, K.; Deng, Y.; Zhang, L.-M. Dendronized chitosan derivative as a biocompatible gene delivery carrier. Biomacromolecule 2011, 12, 642-649. [CrossRef] [PubMed]

87. Tehrani, A.D.; Basiryan, A. Dendronization of cellulose nanowhisker with cationic hyperbranched dendritic polyamidoamine. Carbohydr. Polym. 2015, 120, 46-52. [CrossRef] [PubMed]

88. Pecot, C.V.; Calin, G.A.; Coleman, R.L.; Lopez-Berestein, G.; Sood, A.K. RNA interference in the clinic: Challenges and future directions. Nat. Rev. Cancer 2011, 11, 59-67. [CrossRef] [PubMed]

89. Nam, J.-P.; Nah, J.-W. Target gene delivery from targeting ligand conjugated chitosan-PEI copolymer for cancer therapy. Carbohydr. Polym. 2016, 135, 153-161. [CrossRef] [PubMed]

90. Han, J.; Cai, J.; Borjihan, W.; Ganbold, T.; Rana, T.M.; Baigude, H. Preparation of novel curdlan nanoparticles for intracellular siRNA delivery. Carbohydr. Polym. 2015, 117, 324-330. [CrossRef] [PubMed]

91. Singh, R.S.; Kaur, N.; Kennedy, J.F. Pullulan and pullulan derivatives as promising biomolecules for drug and gene targeting. Carbohydr. Polym. 2015, 123, 190-207. [CrossRef] [PubMed]

92. Wang, L.; Wu, W.; Wang, J.S.; Wang, J.J.; Tong, X.; Hu, Q.; Qi, L. Highly efficient Gab2 siRNA delivery to ovarian cancer cells mediated by chitosan-polyethyleneimine nanoparticles. J. Mater. Chem. B 2016, 4, 273-281. [CrossRef]

93. Gratton, S.E.A.; Ropp, P.A.; Pohlhaus, P.D.; Luft, J.C.; Madden, V.J.; Napier, M.E.; De Simone, J.M. The effect of particle design on cellular internalization pathways. Proc. Natl. Acad. Sci. USA 2008, 105, 11613-11618. [CrossRef] [PubMed]

94. Lin, X.; Zhao, N.; Yan, P.; Hu, H.; Xu, F.J. The shape and size effects of polycation functionalized silica nanoparticles on gene transfection. Acta Biomater. 2015, 11, 381-392. [CrossRef] [PubMed]

95. Ndong Ntoutoume, G.M.; Grassot, V.; Brégier, F.; Chabanais, J.; Petit, J.M.; Granet, R.; Sol, V. PEI-cellulose nanocrystal hybrids as efficient siRNA delivery agents-Synthesis, physicochemical characterization and in vitro evaluation. Carbohydr. Polym. 2017, 164, 258-267. [CrossRef] [PubMed]

(C) 2018 by the authors. Licensee MDPI, Basel, Switzerland. This article is an open access article distributed under the terms and conditions of the Creative Commons Attribution (CC BY) license (http:/ / creativecommons.org/licenses/by/4.0/). 